\title{
The Nonjurors and the Counter Enlightenment: Some Illustration
}

\begin{abstract}
The article argues, firstly, that in view of the relationship between Protestantism and the English Enlightenment it is in distinctively non-Protestant religious thought, within or without the Church of England, that the central themes of the English Counter Enlightenment are to be sought. The writings of the Nonjurors can and should therefore be seen as possessing a wider significance than that derived from the history of theology. They constitute an important part of the Enlightenment/ Counter Enlightenment debates, and this flows naturally from the position they occupy in relation to the Catholic and Reformation traditions. The study exemplifies this view with reference to the writers of the Usager movement. There is, in the second part, a statement of the fundamental theological causes of the Usager schism. The third part displays the significance of these concerns to the Enlightenment/ Counter Enlightenment debates and in particular to the central matter of these debates - the epistemological and institutional location of authority.
\end{abstract}

Discussions of the Nonjurors of late seventeenth- and early eighteenthcentury Britain have habitually found a context in that complex history of the various parties, which, since the sixteenth century, have struggled to have their own definitions of the nature of the Church of England elevated to the status of orthodoxy. It is, however, noteworthy that, in the case of a later party claiming descent from the Nonjurors - that led by John Henry Newman - its profound rejection of certain patterns of characteristically modern thought stemming from the Enlightenment, rather than its relationships to other Anglican factions, has been viewed as its chief claim to continuing attention. Such rejection, it has been argued, raises concern with it from the level of the history of ecclesiastical politics to the sphere of cultural criticism. ${ }^{1}$ If

1. R. Pattison, The Great Dissent: John Henry Newman and the Liberal Heresy (Oxford: Oxford University Press, 1991). Pattison's argument is concerned with Newman himself. However, those themes of Newman adverted to are certainly to be found among his Anglican friends and disciples and implicit in all Roman Catholic thought in the period. Newman's distinction lies in his engagement with an Anglican intellectual tradition which brought him to focus on them.

C. D. A. Leighton lectures in the Department of History, Bilkent University, Ankara. 
this contextualization is acceptable, a fortiori it is likely to prove possible to re-evaluate the wider intellectual significance of earlier groups, confronting less well established Enlightenment beliefs, such as the Nonjurors or the Hutchinsonians of mid-century. Such an approach to the history of High Church thought in the long eighteenth century or, for that matter, the mainstream of Roman Catholic and Orthodox thought to the present day, may well be of some appeal to those with theological interests who find useful J.-B. Metz's concept of "productive non-contemporaneity."

A view of the spectrum of Enlightenment and Counter Enlightenment debate $^{3}$ which allows it to be, with due acknowledgment of historical specificity, assimilated to that of the older confessional conflict provides a preliminary to examination of the Nonjuror conflicts in particular. It seems difficult to fault Henry May, as he speaks of the Enlightenment in the Hanoverian Empire, for electing Protestantism as its pre-eminent adversary. Inevitably in this Protestant world, the greatest number of those who either constructed negative responses to Enlightenment writings or implicitly contradicted them by holding to and developing older positions - both may surely be given the designation "Counter Enlightenment"4 — were Protestants seeking to defend their own religion. However, May qualifies his point by clearly indicating the capacity of Enlightenment thought and Protestantism to coalesce. In the minds of many, he observes, "[f] ar from being in contrast, Protestantism and enlightenment were almost two faces of the same happy history, whose great milestone was the rational and Protestant Revolution of 1688."5 Hardly surprisingly therefore, the stances of the Latitudinarians and Old Dissenters whom Martin Fitzpatrick places together as the English representatives of May's "moderate Enlightenment," were characterized by "a quite immoderate . . . opposition to Roman Catholicism." This coalescence was not the mere product of the juxtaposing of two systems of thought, neither of which the eighteenth-century English mind could disregard. The illustrations of the continuity of some of the most

\footnotetext{
Moreover, Pattison has clearly not exhausted the study of Counter Enlightenment themes in Newman and the drawing of attention to others would establish the fundamental normalcy of Newman's positions, at least as a Roman Catholic.

2. Metz asserts that "[b]y drawing on the resources of a tradition outside the parameters of contemporary thought, it [i.e., Christianity] can offer alternatives which are not available from within the historically limited world of the present. It shows up the historicity of modernity." Indeed, it can "render modernity questionable." See R. Bauckham, "Tradition in Relation to Scripture and Reason," in Scripture, Tradition and Reason: A Study in the Criteria of Christian Doctrine: Essays in Honour of Richard P. C. Hanson, ed. R. Bauckham and B. Drewery (Edinburgh: T. \& T. Clark, 1988), 117-45, 135-6. Metz is no doubt right, but he appears to be ascribing a role to Christianity which is already adequately fulfilled by historiography.

3. The term "Enlightenment" is used here in a rather traditional sense, to refer chiefly to intellectual positions, rather than any wider social phenomenon. Further, the present concern is with those positions which have generally been considered the most fundamental.

4. If this requires justification, it may be pointed out that the parallel term "CounterReformation" is generally required to comprehend spontaneous developments, substantially unconnected with the rise of Protestantism.

5. H. F. May, The Enlightenment in America (New York: Oxford University Press, 1976), xiv$\mathrm{xv}, 3$.

6. M. Fitzpatrick, "Latitudinarianism at the Parting of the Ways: A Suggestion," in The Church of England c. 1689-c. 1833: From Toleration to Tractarianism, ed. J. Walsh, C. Haydon, and S. Taylor (Cambridge: Cambridge University Press, 1993), 209-27, 209-10.
} 
fundamental patterns of thought from the Reformation (and movements of at least heterodox tendency before it) to the English Enlightenment offered by Graf Reventlow, in a study remarkable for both its breadth and depth, will vindicate this point. ${ }^{7}$ More proximate origins of the always imperfect marriage of Protestant and Enlightenment thought lie in the achievement of those, pre-eminently Cambridge men, who created the "holy alliance," spoken of by John Gascoigne, between one major ingredient of English Enlightenment thought, the new science, and Anglicanism. ${ }^{8}$

While it is indeed profitable to seek a common content of Protestant and Enlightenment thought to explain the partial union of the two, it is also useful to consider the structure of the English Enlightenment and Counter Enlightenment debate. This essentially religious debate, as it played itself out in every field of enquiry, was driven by a fear of a drift "towards deism, and even towards atheism." It may easily be thought that the opposite end of the spectrum from atheism - which, if rare in print, was to be everywhere seen in its moral consequences - was constituted by an orthodox Protestantism, in either its Calvinist or Arminian forms. The structural explanation of the coalescence of Protestant and Enlightenment thought lies in the existence of a spectrum, possessing an extensive and extensively endorsed centre, and in the fact that at each point on the spectrum it was claimed, even by the Deists, that Protestant Christianity was being defended on whatever ground was judged to remain tenable.

When, however, the central bulwarks against the Enlightenment are examined, the distinctively Protestant elements in their construction certainly do not constitute the whole. Catholic elements are often more apparent. In this context, the crucial point on the spectrum of the Enlightenment and Counter Enlightenment debate, that at which it was perceived that the integrity of Christianity had been betrayed to rationalist fashion, should be noted. For most, it was doubtless Deism which, by virtue of its shocking extremism, usually appeared to be the most threatening dissolvent of their religion - and of the social and political order which rested on it. However, as Nigel Aston observes, it was often the prominent anti-trinitarians, such as Priestly, who were perceived as "the British counterparts of the French philosophes" in the late eighteenth century, ${ }^{10}$ and equally in the early eighteenth century the more moderate predecessors of Socinians such as Priestly, the Arians, should be

7. H. Reventlow, Bibelautorität und Geist der Moderne: die Bedeutung des Bibelverständnisses fur die geistesgeschichtliche und politische Entwicklung in England von der Reformation bis zur Aufklärung (Göttingen: Vandenhoek \& Ruprecht, 1980). Available in English under the title, The Authority of the Bible and the Rise of the Modern World (London: S.C.M. Press, 1984).

8. J. Gascoigne, Cambridge in the Age of the Enlightenment: Science, Religion and Politics From the Restoration to the French Revolution. (Cambridge: Cambridge University Press, 1989). The extent to which this alliance was ever embraced by Anglicanism as a whole can be questioned. However, since Gascoigne viewed the matter from the banks of the Cam, his depiction is understandable.

9. J. Redwood, Reason, Ridicule and Religion: The Age of Enlightenment in England (London: Thames \& Hudson, 1976) 9-13, 11.

10. N. Aston, "The Dean of Canterbury and the Sage of Ferney: George Horne Looks at Voltaire," Crown and Mitre: Religion and Society in Northern Europe Since the Reformation, ed. W. M. Jacob and N. Yates (Woodbridge, Suffolk: Boydell Press, 1993), 139-60, 142. 
regarded as standing on the chief dividing line between Enlightenment and Counter Enlightenment thought. ${ }^{11}$ Christological debate did not, of course, figure prominently in the polemical conflicts of the Reformation era. However, while it would be wrong to suggest that christology was not of very great importance to eighteenth-century divines, it may be said, at least in retrospect, that it was not its christology that made eighteenth-century Arianism significant. Rather, its significance lay in its foundational assertion of sola scriptura interpreted by the individual's reason (with the latter element underlined), together with the destructive doctrinal consequences which that produced. Here, certainly, was the central epistemological conflict of the Enlightenment, between reason and revelation, as it extended into a conflict about the institutional location of authoritative knowledge. ${ }^{12}$ However, that it did so extend makes it more immediately apparent that here was also the Reformation era's conflict over ecclesiastical authority. It is hardly surprising that Protestants anxious to refute Arian and more extreme views not infrequently found themselves in uncomfortably Catholic positions.

Some, of course, were less uncomfortable than others. The Nonjurors derive their status as the purest and most consistent contemporary opponents of the English Enlightenment in a large measure, as it were, accidentally, by virtue of their pre-existing Catholic stances. On the other hand, it is clear that these stances were sharpened by the experience of contemporary debate. For they did perceive their own argumentation as a response to it and were prepared to explore — for them — new means of combating the positions they found most offensive. The turning of the later William Law and Bishop Archibald Campbell ${ }^{13}$ to personal divine illumination, rather than ecclesiastical authority, as the best alternative to rationalism as the source of authority, illustrates this point.

If indeed the Catholic stances of the Nonjurors are what constituted them as pre-eminent opponents of the early English Enlightenment and consequently make them a bench mark for attempts comprehensively to describe its debate and site individuals and groups within it, then, no doubt, Roman Catholic apologists should also be investigated in the same light. However, the consensus of hostility towards them largely excluded them from the spectrum of

11. J. H. Colligan's The Arian Movement in England (Manchester: Manchester University Press, 1913) is of value only to furnish the names of important authors and their tracts. A brief account of the content of the Arian controversy of the period can be found in R. T. Holtby, Daniel Waterland 1683-1740: A Study in Eighteenth Century Orthodoxy (Carlisle: Charles Thurnam, 1966), chap. 2. For the significance of the debate see J. C. D. Clark, English Society 1688-1832: Ideology, Social Structure and Political Practice During the Ancien Régime (Cambridge: Cambridge University Press, 1985), especially chap. 5. The origins of the debate in the trinitarian controversy of the 1690 s are well placed in the context of the history of the English Enlightenment in J. A. I. Champion, The Pillars of Priestcraft Shaken: The Church of England and its Enemies 1660-1730 (Cambridge: Cambridge University Press, 1992), chap. 4.

12. Champion, 10 .

13. Archibald Campbell (d. 1744) was the nephew of the ninth earl of Argyle, in youth a very ardent Whig and, later, an equally ardent Tory. He was somewhat flawed both in personal character and as a scholar. In 1713 he assisted George Hickes to continue the Nonjuring succession. Despite misgivings, the clergy of Aberdeen elected him as their bishop in 1721, though before, during, and after his brief career as bishop of Aberdeen he resided in London. 
English debate, a circumstance they themselves recognized by their very frequent refusal, throughout the eighteenth century, to enter "into any Disputes between Christians of any Denomination" and indeed to adopt, when dealing with current conflicts, the stance of a member of the established church. ${ }^{14}$ In view of this, there is merit is perceiving the Nonjuring movement as Roman Catholicism's surrogate in the context of the English Enlightenment debate.

At the same time, the limits of Nonjuring Catholicism are to be noted. It is certainly true that " $[\mathrm{t}]$ he Non-Jurors shared with the great majority of their fellow countrymen a Protestant, anti-Roman consensus" 15 and contemporary accusations of crypto-Popery against the Nonjurors are no more to be accepted at face value than similar Puritan attacks on Jacobean conformists and Laudians. ${ }^{16}$ No reading of Nonjuror writings with observation of their sources would suggest a Romanizing program, though the existence of the Jansenist and Gallican debates in France in the period and the interest in these in England, where they were often seen as fundamental challenges to the character of Catholicism, is not to be discounted as an influence. Granted that they were not deliberate Romanizers, the question of their position in relation to Anglican and Roman Catholic thought remains. The most marked Catholic trends are to be sought among those Nonjurors who espoused the cause of the four liturgical innovations in the eucharist, known as the usages - a prayer of oblation, an epiclesis, prayer for the dead and a mixing of water with the wine. The dispute over these began in 1716 and created a schism which was only partially ended in 1732 . Notably, Thomas Deacon ${ }^{17}$ and Campbell remained unreconciled. The Usagers' support for these positions in themselves was hardly extreme. In the matter of prayer for the dead, for example, there was certainly some Caroline precedent for their stance. ${ }^{18}$ Later, William Wake, the future archbishop of Canterbury, did "not presume to condemn" the practice tout court, as patristic sources, which he cited and commented on, commended it. He merely opined that it was unnecessary and inexpedient, in that it might lead to acceptance of the Roman doctrine on purgatory. ${ }^{19}$ Deacon shared Wake's disapproval of this teaching and, though

14. S[imon] Berington, Dissertations on the Mosaical Creation ... (London, 1750), [4] and [7]. 15. E. G. Rupp, Religion in England 1688-1791, Oxford History of the Christian Church. (Oxford: Oxford University Press, 1986), 7.

16. In response, the Nonjurors oscillated, as High Churchmen since the early seventeenth century had always done, between pointing out the unhappy consequences of excessive antiRoman zeal and pointing out, often not very convincingly, the differences between their positions and Rome's. See, for example, Thomas Brett, Tradition Necessary to Explain and Interpret the Scriptures ... (London, 1718), 49 and Thomas Deacon's work on prayer for the dead cited below, n. 20.

17. Thomas Deacon (1697-1753) was ordained by his stepfather, Bishop Jeremy Collier, in 1716. He was at once involved in the Usages conflict (see below) and remained, with Archibald Campbell, committed to that cause after most others had made their peace with the main body of Nonjurors in 1732. He spent his adult life in Manchester, where he presided over his congregation and had a medical practice.

18. See, for example, the views of William Forbes, the bishop of Edinburgh, cited by A. Milton in his Catholic and Reformed: The Roman and Protestant Churches in English Protestant Thought, 1600-1640 (Cambridge: Cambridge University Press, 1995), 68.

19. [William Wake], Two Discourses: of purgatory and prayers for the dead (London, 1687), $66-9$. 
it was no doubt to refute in advance any accusations of crypto-Popery, framed his defence of the practice as a piece of argumentation against it, claiming that "our prayer for the dead is entirely inconsistent with Popery." perhaps less than honest: the Usagers' thought was indeed somewhat at variance with the teachings of Trent, but their practice was not. Still, in this way, Deacon was able to give some appearance of agreement in principle with members of the regnant church.

That he desired to do so and could do so, is significant. So too, however, are the remaining differences. Wake acknowledged that the practice of the early Christians was to pray for the dead, but was firm in asserting that "they never put it into any of their Creeds" and held that it could not be de fide for lack of scriptural warrant. ${ }^{21}$ The essential mark of the Usager, on the other hand, was an insistence that the matter was de fide and thus warranted separation. Such differences were in fact revelatory of an underlying tendency among the Usagers, which led to the creation of a religious body which remained only historically associated with the Church of England. In the end, Deacon declared an unwillingness to condemn the Roman Church any more than the Church of England. ${ }^{22}$ The substantially slighter degree of deviance from the contemporary Anglican norms among the Non-Usagers was the expression of and the basis for their hopes of eventual re-union with the regnant church. Henry Broxap emphasized that the importance of such hopes and Usager indifference to them constituted an underlying reason for the establishment and continuation of the schism. ${ }^{23}$ However, this Non-Usager moderation was unlikely to do much to alter the perceptions of them held by most members of the regnant church. Fundamentally, this was determined by the anti-Catholic tradition. At the heart of this tradition was the claim that Catholicism could be adequately described as a system of false religion, cynically constructed and propagated to enhance the political power of the clergy and in particular of the pope. ${ }^{24}$ Thus in the sacramentalist and therefore clericalist creed of the High Churchmen, inherited by Usager and NonUsager alike, it was the very essence of Popery - and the essence of what an Enlightenment with a rallying cry of "Let us detest all priestcraft" most opposed — that was discerned. In this light, no High Church argumentation can be excluded from the corpus of English Counter Enlightenment writings. In devoting the remaining part of this article to the Usager debate, generally regarded as having a decidedly peripheral character, some illustration is

20. Thomas Deacon, The Doctrine of the Church of Rome concerning Purgatory Proved to be contrary to Catholic Tradition ... (London, 1718), xxiii-xxiv. Bishop Campbell was also anxious to contrast his views with those of Rome. See his Doctrines of the Middle State between Death and the Resurrection ... (London, 1721), xvi-xvii.

21. [Wake], Two Discourses, 48, 69.

22. See, for example, Deacon to Pierce, 4 May 1750. Manchester, Chetham's Library, Mun. A6. 71. Transcription of a letter in the Scottish Episcopal Church Library, Edinburgh.

23. Henry Broxap, A Biography of Thomas Deacon: The Manchester Non-Juror. (Manchester: Manchester University Press, 1911), 93; idem, The Later Non-Jurors (Cambridge: Cambridge University Press, 1924), 50-1, 66.

24. C. D. A. Leighton, Catholicism in a Protestant Kingdom: A Study of the Irish Ancien Régime (London: Macmillan, 1994), 49-51. 
offered of the consistency with which this classification can be applied and provide an interpretative key to a body of work which still deserves to be read. The general failure thus to classify them has tended both to conceal some of their most fundamental concerns of the Nonjurors and isolate these writers from the intellectual currents of their time.

Ernest Rupp passed over the Usager dispute quickly, complaining that it was "an intricate story, a rigmarole of personal relations." 25 Since it has so appeared, it is necessary to rise above the narrative somewhat and establish the main areas of contention. Their significance to the intellectual currents of the time can then be seen. Rupp referred the curious reader to Broxap, who had indeed told the story, but with little sympathy for the Usager stance on "questions which could hardly be said to be of the first importance."26 However, that was little more than a restatement of the charge made by their contemporary opponents. The Usagers took their stand precisely because they believed that the four usages did indeed constitute "an essential Part of Religion, and [were] of absolute Necessity in Order to Salvation"27 in that they were of dominical institution and thus necessary for the validity of the eucharist. ${ }^{28}$ While such a stance is readily understandable with regard to the prayer of oblation and the epiclesis, it appears considerably less defensible with regard to prayer for the dead and the mixed chalice. It might be pointed out that an assertion of the equal importance of the practices commended was but a function of the mode in which the debate was conducted. When the four usages were declared to be the irreducible demands of a party, it became difficult to give the appearance of understating the importance of any of them. However, it is more important to note the reasons the Usagers themselves gave - the desire to preserve the validity of the eucharist and the desire to obey a body of divine positive law communicated by tradition. The matter of tradition in particular took up "a great Part of the Controversy on both sides" 29 and the former matter was by no means neglected. This will better justify them against charges of a lack of theological sophistication and indifference to any hierarchia veritatum.

The defence of the usages developed chiefly as an assertion of the importance of tradition as a source of revelation. It sprang from a concern to defend a doctrine of the eucharistic sacrifice, which, for all the predictable and partially true assertions that it was the traditional doctrine of the Church

25. Rupp, 21.

26. Broxap, Later Non-Jurors, 63.

27. Thomas Brett, A Farther Proof of the Necessity of Tradition, to Explain and Interpret the Holy Scriptures . . . (London, 1720), vii.

28. See, for example, [John Griffin], The Common Christian Instructed in Some Necessary Points of Religion ... in Answer to Mr. S[amuel] D[ownes]'s' Abridgment of the Controversy, $\& c \ldots$ (London, 1722), 2.

29. [Griffin], Common Christian, 4. 
of England, was now certainly somewhat at variance with the mainstream of Anglican opinion. The Usagers might not have found much to quarrel with in Wake's view, which would have allowed the use of the word "sacrifice," indeed "propitiatory sacrifice," in relation to the Eucharist, in that in it Christ's sacrifice was indeed "presented" or "represented." ${ }^{30}$ On the other hand, Ralph Cudworth's formulation, asserting that the Eucharist was no sacrifice, but "a Feast on a Sacrifice," had proved more attractive. ${ }^{31}$ One of the most important sources of Usager inspiration was undoubtedly Bishop George Hickes ${ }^{, 32}$ treatment of the matter. Hickes regarded this as a most important topic and took the trouble to expand his initial brief treatment very considerably. ${ }^{33} \mathrm{He}$ would have written at even greater length, had he not been old and sick, "worn out in the Service of Primitive Christianity." The urgent task thus devolved on his friend, a clergyman of the regnant church, John Johnson of Cranbrook. ${ }^{34}$ The Usagers inclined to look on Hickes, who died in 1715 just before the emergence of the controversy, as the first of their number. In truth, though, as Deacon acknowledged, the bishop did not maintain that the four usages were essential, as they did. ${ }^{35}$ Both Hickes and Johnson indicated their approval of the usages, but only quite incidentally in the course of their defence of the sacrifice and a due sense of theological proportion was maintained. ${ }^{36}$ The Usagers themselves showed an inclination, when discussing the lesser matters, to relate them to the doctrine of the eucharistic sacrifice. Thus, for example, Archibald Campbell, having offered a justification of liturgical prayer for the dead in ecclesiological terms, speaking of the communion of saints, defends it further on the grounds of its demonstration of the union of the eucharistic sacrifice with the sacrifice of Calvary, which was also offered for the dead. ${ }^{37}$

The doctrine of the Eucharist remained important throughout the dispute. One singularly immoderate Usager tract, which with its abandonment of any pretense of dialogue with the Non-Usagers no doubt reveals the Usager mind with greater clarity than most, placed the defence of eucharistic doctrine alongside defence against the chief rationalist assault on contemporary

30. [William Wake], An Exposition of the Doctrine of the Church of England, in the Several Articles proposed by Monsieur de Meaux . . . (London, 1687), 63. Cf. Deacon, Concerning Purgatory, xxv.

31. Quoted in John Johnson, The Unbloody Sacrifice, and Altar Unveiled and Supported. (London, 1718), 2: iii.

32. George Hickes (1642-1715) had declined the see of Bristol, out of hostility to the policies of James II, and the Revolution found him dean of Worcester. In 1694 he was consecrated with Thomas Wagstaffe to continue the Nonjuring succession. When, after Wagstaffe's death in 1712, there were attempts to heal the schism, Hickes led the intransigents and performed further consecrations.

33. George Hickes, Two Treatises, One of the Christian Priesthood, the Other of the Dignity of the Episcopal Order, $3 \mathrm{~d}$ ed. (London, 1711), 1: 1st roman sequence, iii.

34. Johnson, Unbloody Sacrifice, 2d ed. (London, 1724), 1: xxxviii. Johnson of Cranbrook (1662-1725) wrote almost exclusively on eucharistic theology. He was educated at Magdalene and Corpus Christi, Cambridge. Though an intimate of the Nonjurors, whose theological views he shared, he retained the living of Cranbrook in Kent, which he obtained from Archbishop Tenison in 1707 , until his death.

35. Broxap, Later Non-Jurors, 40-4, 66.

36. See, for example, their references to the epiclesis. For Hickes, see Two Treatises, 1: 92-8.

For Johnson, see Unbloody Sacrifice, 1: xvii-xviii.

37. Campbell, Middle State, 148. Cf. Deacon, Concerning Purgatory, $\mathrm{x}-\mathrm{xii}$. 
Christianity, declaring "that the Devil hath exercised and vented more Malice and Spite against this Holy Rite, than against any other part of the Christian Religion, except the Doctrine of the Holy Trinity." The rejection of the sacrifice meant that the Christian covenant was not renewed, grace was denied and the nation was consequently brought to ruin. ${ }^{38}$ However, although the Usagers were seriously concerned about eucharistic doctrine, it was the question of ecclesial tradition which emerged to dominate the debate. Thomas Brett, the most able scholar among the Usagers, ${ }^{39}$ in the preface of perhaps the most enduring work produced by the dispute, his Collection of Liturgies, set out the pattern of the dispute between Usager and Anti-Usager with admirable clarity. The Non-Usagers first

endeavour'd to wrest the Scriptures from [the Usagers] . . . and then argue, that Tradition without Scripture is not of Authority enough to establish a Doctrine, or found a necessary Practice upon: And likewise, that the Tradition pleaded for these Usages, is not so full and unexceptionable as it is pretended to be. ${ }^{40}$

The wresting of the scriptures was not a difficult task: the Usagers generally allowed their opponents to advance that far. Thus, leaving aside the battle of patristic proof texts relevant to the four usages themselves, the most important Usager arguments were intended to extend the use of supplementary tradition, that is, that tradition necessary to supplement scripture in order to establish the content of the faith. ${ }^{41}$

Indeed, the Non-Usagers, like Anglicans as a whole, were profoundly uncomfortable with the notion of a supplementary tradition. They might readily admit a willingness to accept such traditions as might be shown to have been received semper, ubique et ab omnibus. However, they were not always careful to specify whether or not they considered that such traditions, if not provable from scripture, were to be received de fide. ${ }^{42}$ On the whole, though, the Non-Usager, Bishop Nathaniel Spinckes ${ }^{43}$ was stating a normal contemporary Anglican position when he declared that "Tradition must by no means interfere with Scripture . . by teaching anything, as of Necessity for Salvation, which that does not teach at all." This Brett quoted and set out to refute. ${ }^{44}$ The

38. [Minors], The Subtilty of the Serpent, in Corrupting the True English Liturgy (London, 1718), 5-19, 13.

39. Thomas Brett (1667-1743) was educated at Queens' and Corpus Christi, Cambridge. His Tory convictions and Nonjuring sympathies developed during the reign of Queen Anne, though he continued to hold his livings in his native Kent until 1714. He was consecrated bishop with Henry Gandy in 1716. Brett rejoined the main Nonjuror body in 1732 .

40. Thomas Brett, A Collection of the Principal Liturgies, Used by the Christian Church in the Celebration of the Holy Eucharist ... . (London, 1720), iv.

41. For a historical survey of various understandings of tradition, see Bauckham, "Tradition in Relation to Scripture and Reason," 117-25.

42. See, for example, [Samuel Downes], An Abridgment of the Controversy between the Church of England, and the New Pseudo-Primitives . . . 2d ed. (London, 1722), 4-5.

43. Nathaniel Spinckes (1653-1727) was a prebendary of Salisbury before the Revolution. He was among those whom Bishop Hickes had consecrated in 1713 to continue the succession (see n. 32). He is, in fact, to be regarded as the leader of the Non-Usagers; but on account of his maninifest piety, he retained very general respect.

44. Brett, Farther Proof of the Necessity of Tradition, 3-26. Cf. Wake, Doctrine of the Church of England, 75-6. 
Usagers, however, perceived a chink in the armour - the matter of the scriptural canon. ${ }^{45}$ Even William Chillingworth, the most famous upholder of the belief that the Bible alone was the religion of Protestants, had rested the canon on "the Credibilitie of Universal Tradition." 46 Thrusting forward the canon and other unexceptionable beliefs they held to be defensible only on the grounds of tradition, such as the desirability of infant baptism, ${ }^{47}$ the Usagers went on to press their opponents for clear acceptance of a supplementary view of tradition and its ability to justify their own eucharistic practices. The Non-Usagers had inherited a certain lack of clarity on the question of tradition from Anglican theology and added to the confusion by failing to state even that position at all well. The Usagers' attacks on their opponents certainly manifested a belief in a clear position. However, it was not always well expressed. They frequently muddied the waters of debate by failing to distinguish different kinds of belief in tradition by, for example, accusing the Non-Usagers of rejection of the authority of tradition altogether ${ }^{48}$ or, again, citing as supportive of their own position mere commendations of the use of the fathers for the interpretation of scripture. ${ }^{49}$ And if the Usager exposition of the concept of tradition was less than wholly clear, it was also rather narrow. In one respect, this was inevitable, in that they inherited the Anglican apologetic insistence, against the Tridentine formulation, that tradition was a written thing, to be explored by normal historiographical methods. ${ }^{50}$ Less excusable was a failure to take a view of tradition as comprehending the entire life of the church, such as had been held by such men as William Cave. ${ }^{51}$ As Deacon confessed to Charles Wesley, he had, throughout his life, scanned the fathers only with a view to ascertaining the liturgical and disciplinary practices of early Christianity. ${ }^{52}$

The Usagers, freed by their separation from those who continued to hanker after re-union with the regnant church, developed into a denomination, which became known, after a partial re-union with the Non-Usagers in 1732, as the Orthodox British Church. ${ }^{53}$ Its chief characteristic, shaped in the dispute on the question of tradition, was undoubtedly a desire to reconstruct, historiographically and in practice, what they called "primitive Christianity." It was his lifelong devotion to this religion that either Deacon himself or those closest to him chose as the most salient point of his biography and fit to

45. See, for example, Deacon, Concerning Purgatory, xv-xvi. It should be noted that this Usager concern with the canon was not wholly a matter of polemical opportunism.

46. Quoted in G. Reedy, The Bible and Reason: Anglicans and Scripture in Late SeventeenthCentury England (Philadelphia: University of Pennsylvania Press, 1985), 94, 96.

47. See, for example, [Jeremy Collier], A Vindication of Reasons and Defence, \&c. (London, 1718-9), 2: 11.

48. See, for example, Brett, Farther Proof of the Necessity of Tradition, xix.

49. See, for example, Thomas Wagstaffe's preface to John Grabe's De forma consecrationis eucharistiae... (London, 1721), iv-xxii.

50. See, for example, [Collier], A Vindication, 1: 37.

51. See, for example, Cave's Primitive Christianity: or, the religion of the ancient Christians 4th ed. (London, 1682) or his Lives of the Most Eminent Fathers of the Church that Flourished in the First Four Centuries . . . 3 vols. (Oxford, 1840).

52. Broxap, Thomas Deacon, 75-6.

53. Broxap, Thomas Deacon, 89-101. 
record on his tomb, under the walls of St. Anne's Church in Manchester. The phenomenon of what has been called "primitivism" is, of course, a widespread one in the history of Christianity ${ }^{54}$ and this antiquarian form of it existed among the Usagers' contemporaries. Embarrassingly for the Usagers, the most prominent of these contemporaries was William Whiston, the former Cambridge academic, who had become convinced "that the trinitarian doctrine of the complete identity of the Son with the Father was a false accretion to original, 'primitive' Christianity" seeking to revive the so-called Clementine liturgy, the favoured text of the Usagers. ${ }^{56}$ No doubt the Usagers believed that Whiston's Arian interpretations of patristic sources were adequately refuted by such scholars as John Grabe. ${ }^{57}$ However, the similarity of Whiston's approach to their own might have given them cause to consider if their careful reconstruction of Christian antiquity was not in fact a seriously flawed method of engaging in combat against the English Enlightenment. For that was what they were engaged in.

\section{III}

Description, such as is offered of the Usager movement above, rather than argument, suffices to establish the opposition between this and that moderate Enlightenment, represented by the mutually sympathetic Latitudinarians and Old Dissenters. Two elements of the position of these latter were primary their firm adherence to the sixth Article and their rationalism. Their belief that all salvific truth was ascertainable from scripture allowed them to dismiss all other matters as indifferentia and insist on the ready accessibility of scriptural truth. The latter point found confirmation from their optimism about human reason. A rationalist inclination applied to the understanding of faith produced a diminished concern with adherence to orthodox positions. For, as intellect was magnified at the expense of will in the formation of faith, heterodoxy became less morally offensive. ${ }^{58}$ Since the Usager movement, with its insistence on the absolute necessity for salvation of matters derived from tradition, by its mere existence constituted as fundamental a contradiction of

54. See, for example, T. D. Bozeman, To Live Ancient Lives: The Primitivist Dimension in Puritanism (Chapel Hill, N.C.: University of North Carolina Press, 1988).

55. J. E. Force, William Whiston: Honest Newtonian (Cambridge: Cambridge University Press, 1985), 16. See also 19-20.

56. The Clementine liturgy is in the eighth book of the Apostolic Constitutions, an Arian or Apollinarian compilation of the later fourth century. Whiston's espousal of Arianism rested on the conclusion that this work was genuinely of apostolic date. Taking a different view of the work's doctrinal content, the Usagers, following the lead given by Brett in his Collection of Liturgies, gave up their enthusiasm for the First Edwardian Prayer Book and adopted the Clementine liturgy as the one most appropriate for the followers of primitive Christianity. See Broxap, Later Non-Jurors, 40-2.

57. [John Ernest] Grabe, Some Instances of the Defects and Omissions in Mr. Whiston's Collection of Testimonies from the Scriptures and the Fathers . . . (London, 1712). The work has an introduction by Bishop Hickes.

58. Cf. Fitzpatrick, "Latitudinarianism," 211. 
these principles as can be imagined, it is unsurprising that Usager texts offer numerous refutations of specific points. There are, for example, the refutations of the belief that salvific truths are delivered "so as they may be plain and easy to the meanest Capacity, and that whoso reads [the scriptures] may understand them," "59 though this was hardly ad rem in establishing a supplementary view of tradition. However, multiplication of such citations would be superfluous. The inherent Counter Enlightenment character of Usager positions, given to them by their predominantly seventeenth-century origins, is clear enough. It is of more interest to enquire about the extent to which contemporary Enlightenment debates strengthened commitment to or even brought about the adoption of those positions.

This question is, however, a difficult one. It certainly does not appear that all Nonjurors were becoming preoccupied with contemporary challenges to the exclusion of older ones. Charles Leslie, ${ }^{60}$ in the prefatory Epistle to the collected tracts, emphasized that his efforts had been "against the several Enemies of the Christian Religion, and of the Church of England." Jews, Quakers, and Papists were just as much his concern as Deists, Socinians, and the "modern Innovators" who undermined the church with Whiggish principles. ${ }^{61}$ The intellectual contempt expressed in the title of his thirty-page anti-Deist tract, $A$ Short and Easy Method with the Deists, reveals his mind as well as his polemical skill. ${ }^{62}$

On the other hand, there are, in the writings of the Usagers on the Eucharist and ecclesial tradition, such frequent assertions of concern with new threats, not merely to their own vision of the church, but to Christianity and demonstrations of the relevance of their work in the combating of those threats, that the inclination to construe that work as originating in those concerns is inevitable. The mentor of the Usagers in eucharistic theology, Johnson of Cranbrook, offers a convenient example. The Prefatory Epistle of his Unbloody Sacrifice does indeed show an awareness that the polemics in which he was engaged constituted a continuation of those of the earlier seventeenth century ${ }^{63}$; but the piece chiefly displays a concern to rally all Anglican opinion behind what the author believed to be the most viable position for the defence of the church from contemporary dangers. It was addressed in conciliatory fashion to Bishop Charles Trimnell, who had declared his opposition to Johnson's

59. Brett, Tradition, 29.

60. Charles Leslie (1650-1722) was rather more than the best of the Nonjuror pamphleteers, though he was that, and the persecution he suffered witnesses to it. He also possessed a real capacity for theology, reflected in Samuel Johnson's well-known remark that he was "a reasoner who was not to be reasoned against." Of Irish origin, he was educated at Trinity College, Dublin, and became chancellor of Connor. His career as a Nonjuror, however, was pursued mostly in England. He was no supporter of the Usagers, whose excessive dependence on historical method he deemed unsafe.

61. Charles Leslie, The Theological Works of . . . (London, 1721), 1, unpaginated prefatory "Epistle."

62. Leslie, Theological Works, 1: 1-30. The full title is: A Short and easy Method with the Deists, wherein the Certainty of the Christian Religion is demonstrated by Infallible Proof from Four Rules, which are Incompatible to any Imposture that ever yet has been, or that can possibly be. In a Letter to a Friend.

63. Johnson, Unbloody Sacrifice, 1: xxviii-xxix. 
views, and it cited Latitudinarian support when it was to be had. ${ }^{64}$ Even the Dissenters got off lightly. They were no longer the real enemy, having "of late Years, in a great measure, forfeited their Credit with the People of our Communion." It was those with whom they allied themselves, but whom "they would soon find, by dear-bought Experience, that these . . . [were] no more Friends to their Principles, than ours," who were now to be guarded against. These were the "Men of short Creeds," who held the Anglican "Creeds to be Popery, and ... would reduce our Christian Faith to one single Article, that Jesus is the Messias, and look upon that too, as far from being necessary." They were "known Enemies of every thing, that is Mysterious, and above Reason" and who had "Machiavel, Algernon Sidney, and such like Writers, ... . [as] their Oracles in relation to Civil Government; and Socinus, Toland, or Blunt, [sic] as to matters of Religion." Since agreement with those who held views such as these was manifestly impossible, those who adhered to the church should adopt unequivocally Anglican positions. ${ }^{65}$

Johnson had begun his work by making it clear how a defence of the eucharistic sacrifice constituted a refutation of the "Men of short Creeds." Heterodox christology was to be assaulted through its soteriology. For his arguments in eucharistic theology necessarily involved a countering of "the Objections made by the Socinians against the Perfection of our Saviour's Sacrifice [on Calvary]," in that it obligated a general discussion of the nature of sacrifice. ${ }^{66}$ However, it would be wrong to draw attention to this explicit statement of Johnson's intention to engage in the central, trinitarian debate of the English Enlightenment, without drawing attention also to the related conflicts such engagement would necessarily involve him in - and it is hardly to be thought unwillingly. The defence of the eucharistic sacrifice, it may be pointed out for example, was the theologically necessary preliminary to assertions of clerical authority, the more immediately important complement to Counter Enlightenment epistemological arguments. This relationship is clear from the context in which Bishop Hickes's defence of the eucharistic sacrifice arose - his discourse on the powers of the priesthood and the episcopate in his Two Treatises. It is noteworthy that Johnson's eucharistic treatise was prefixed by expressions of anxiety about anti-clericalism, expressed as warnings of possible persecution. ${ }^{67}$ Again, it is very clear that Johnson was engaged in challenging that Latitudinarian moralism, which the Methodists would so often dub "Pelagianism." One can hardly find a more direct challenge to it than Johnson's assertion that sacrifice constituted the most fundamental Christian duty, under which all others were subsumed ${ }^{68}$ - a statement which was a justification of Johnson's choice of theological subject matter throughout his life. The ramifications of this might be pursued

64. Johnson, Unbloody Sacrifice, 1: xx.

65. Johnson, Unbloody Sacrifice, 1: xxv-xxvii.

66. Johnson, Unbloody Sacrifice, 1: i.

67. Johnson, Unbloody Sacrifice, 1: xxiv-xxv, xxvii, xxx-xxxi.

68. John Johnson, The Primitive Communicant: in three discourses on the sacrament of the eucharist . . . 2d ed. (Manchester, 1738), 38-9. 
by considering Reventlow's characterization of the English Enlightenment as deriving from enduring tendencies in European thought to moralize religion and seek personal religious experience unmediated by the externals of religion (developing into individualistic rationalism) ${ }^{69}$ In brief, if Johnson's declared purposes seem narrow, the relationships of his arguments should be taken into account. It then becomes clear that his work represents a wideranging assault on central Enlightenment positions. Further, it seems that the desire to make such an assault was very probably an important motivation of Johnson's work and certainly a major formative influence on it.

If the discussion of sacramentology was the necessary preliminary to the assertion of ecclesiastical authority against rationalism, the other dominant theological concern of the Usagers, with ecclesial tradition, brought them to the heart of the debate around this most fundamental of Counter Enlightenment assertions. For the emergence of rationalism in its seventeenth- and eighteenth-century English form owed a very great deal to Anglican adherence to the principle of sola scriptura. Even in Chillingworth the principle had produced tendencies to individualistic rationalism and an eviscerating emphasis on the moral content of Christianity ${ }^{70}$ Still, Gerard Reedy is undoubtedly justified in emphasizing that the rationalism of his Latitudinarian successors was hardly of an extreme sort and was upheld with conservative intention. ${ }^{71}$ However, by the time of the Usager controversy, such writers as Locke had developed methods of interpretation which far more radically denuded the scriptures of such conventional aids to understanding as approach through dogmatic debate. When dogmatic arguments reemerged from this process they were inevitably alarming. This dissolution of the dogmatic structure of Christianity was made manifest in the trinitarian disputes of the 1690s and the Arian controversy around Whiston and Samuel Clarke, which were contemporary with the Usager dispute.

This particular contemporary context is not readily apparent from the Usager texts, firstly, since there was as yet no conviction that it was necessary to acknowledge that trinitarian doctrine could not be defended without the aid of a supplementary tradition. However, the more perceptive were disturbed. Even before Clarke, easily the most effective of the heterodox in wresting control of Scripture, entered the trinitarian debate, George Hickes declared its bringing of the divinity of Christ "into Controversy" a good reason to depart from a strict sola scriptura doctrine. ${ }^{72}$ The scantiness of reference to the trinitarian conflict derives also from the polemical advantage in making reference to even more extreme writers than anti-trinitarians like Clarke. For example, it may be noted that the Usagers' use of the question of the biblical canon in their debates was related to the contemporary scandal caused by the publication of John Toland's Nazarenus: or Jewish, Gentile and Mahometan

69. See n. 7, above.

70. Reventlow, 147-52.

71. Reedy, 10-12.

72. Hickes, Two Treatises, 1: 145-6. 
Christianity. In this Toland attempted to reject the fundamental Christian doctrines as accretions on a primitive Christianity, which he attributed to the early Jewish followers of Jesus and which was substantially the same as the religion preached by Moses, Mohammed and, of course, contemporary Deists. $^{73}$ Interest in the Judeo-Christian sect known as the Nazarenes or Ebionites was not new ${ }^{74}$ and what chiefly provoked the orthodox answerers of Toland, such as Thomas Mangey of the regnant church as well as Brett, was the attack on the biblical canon, which Toland's Nazarene religion could not accommodate. ${ }^{75}$ Brett indicated that he considered his Tradition Necessary to Explain and Interpret the Scriptures, which, with his Collection of Liturgies, must be ranked the best study contributed to the Usager debates, constituted an effective reply to the Nazarenus and turned the preface of his work into critique of it. He pointed out that if the authority of ecclesial tradition could be upheld, the canon was secure and Toland's fanciful understanding of Christian origins fell to the ground. ${ }^{76}$

That we should be aware of a more fundamental concern - with the source of intellectual authority - among the Usagers than that with sacramentology or ecclesial tradition, is made plain by the interest they showed in finding an alternative, or at least a complement, to the latter. One alternative, the episcopally taught Church of England of the eighteenth century, was, by the reality of their situation, largely denied to them. It was not so for other Nonjurors, who held a more positive view of the regnant church. Leslie, for example, approached the question of authority in a quite traditional way, with a discussion of the right of private judgment. The ever more conspicuous rationalism of his age brought him to uphold a position very close to the Roman one, Something less than his usual clarity attended his effort to articulate a distinctively non-Roman position, but one which allowed "the Church to be the Judge of Faith, the only and supreme Judge of it upon Earth." Only an interior dissent from its teaching was lawful. ${ }^{77}$ The Usagers certainly accepted Leslie's stance. However, the church before whom the believer was "to lay aside all modern hypotheses . . . and private opinions [was] ... the ancient and universal Church of Christ from the beginning to the end of the fourth century." ${ }^{, 78}$ Leslie perspicaciously warned that this Usager desire to rest all on historical argumentation was foolish. It was to "launch into an ocean which has neither Shore nor Bottom,... [ [without] any compass to

73. P. Harrison, "Religion" and the Religions in the English Enlightenment. (Cambridge: Cambridge University Press, 1990) 165-7. see also Champion, 125-31.

74. Nor, it might be added, did it disappear. In the mid-eighteenth century the Socinian patristic scholar, Nathaniel Lardner, described his opinions on the divinity of Christ as the "Nazarean Doctrine." See Nathaniel Lardner, The Works of . . . (London, 1838), 9, 591-606. Even at the present day, writers can be found who maintain the existence within early Christianity of a distinct body of Jewish believers, possessed of distinctive doctrines. The view is hardly tenable. See J. E. Taylor, Christians and the Holy Places: The Myth of Jewish-Christian Origins (Oxford: Oxford University Press, 1993), chap. 2.

75. Champion, 109-10, 113, 123, 126.

76. Brett, Tradition, i-xxiii.

77. Leslie, Works, 1: 175-89, 193, 187.

78. Quoted in Broxap, Thomas Deacon, 173. 
steer by." ${ }^{, 79}$ However, the Usager degeneration into a sect-like condition substantially forced them to adopt this course.

There were, however, inclinations to plot others. It may be thought surprising that it is possible to find divine illumination set against rationalism in the Nonjuror texts. Law's adherence to a belief in "the Sufficiency of the Divine Light, and Necessity of seeking only the Guidance and Inspiration of the Holy Spirit" ${ }^{\prime \prime 0}$ is well known, but has been regarded as constituting a feature of his singularity, as a mystic, among his fellow Nonjurors. In the light of Andrew Weeks's convincing presentation of the view that mysticism is deeply concerned to assert not merely religious, but confessional authority and is indeed shaped by the challenges to that authority, ${ }^{81}$ Law may appear much less singular. In any case, Law's adherence to this belief was not extreme. He criticized the Quakers for making this "their Corner Stone." 82 Further, his stance was not without Nonjuror precedents. Bishop Campbell accepted that some would "call me an Enthusiast, for what I have said of the Charismata, and of the Spirit." 83 The charge, he made clear, would not have been unjustified. Campbell ultimately rested his arguments for an intermediate state and a purification between death and resurrection, as other Usagers did their arguments for the doctrines and practices they sought to defend, on the authority of the Fathers, who, living in the "Ara of the Charismata," were "illuminated" or "Anointed by the Unction of the Holy Ghost from on High." What rather distinguished Campbell was his further reflection on this illumination and his explicit statement of his conclusions. With regard to its significance, he considered that "this Divine Illumination, this Heavenly Unction . . . [conferred] the only true Christian Infallibility." 85 More striking was his opinion about who possessed this infallibility. The apostles themselves did not possess it in its plenitude, they did not pass it to their successors and it did not inhere in general councils. Nor was it limited to the first ages of the Church. At first glance, Campbell's readers may have been alarmed by this promiscuous diffusion of authority among Christians. They were no doubt consoled to find out that neither the Roman hierarchy, who had corrupted the faith, ${ }^{86}$ nor the clergy of the regnant church, who were so frequently guilty of "Covetousness and Ambition, two very deadly Sins," nor the dissenting clergy, who were satanic pretenders to ecclesiastical authority, could possibly, by virtue of these sins, be in possession of that illumination which gave infallibility. ${ }^{87}$

79. Transcription of Charles Leslie's A Letter from Mr. Lesly to his Friend . . (London, 1718). Manchester, Chetham's Library, pamphlet volume 4C.7.71, item 5.

80. William Law, "Some Animadversions upon Dr. Trap's Late Reply," in his An Appeal to All that Doubt, or Disbelieve the Truths of the Gospel . . (London, 1742), 215-332, here 275. The "Animadversions" was published separately two years before.

81. A. Weeks, German Mysticism from Hildegard of Bingen to Ludwig Wittgenstein: A Literary and Intellectual History (Albany: State University of New York Press, 1993). See especially $10-13$.

82. Law, An Appeal, 275.

83. Campbell, Middle State, 153.

84. Cf., for example, Brett, Tradition, chap. 15.

85. Campbell, Middle State, 240.

86. Campbell, Middle State, 242-5.

87. Campbell, Middle State, 257-9, 258. 
Nonjuror interest in using divine inspiration as an alternative to the authority of individualistic rationalism was not considerable, except in the admittedly very notable case of Law. Nevertheless, it is noteworthy as confirming the importance of the search for such an alternative in Nonjuror thought. It is the existence of that search which should be seen as the fundamental link between the Nonjuring movement and other Counter Enlightenment movements, such as Hutchinsonianism. The adherents of this movement were in a happier situation than the Nonjurors, in that they found it possible to place comparatively little emphasis on ecclesial tradition, to denounce enthusiasm and to declare their adherence to the principle of sola scriptura and maintain "Scripture language ... [to be] the only explainer of itself." 88 In reality, of course, the Hutchinsonians had found another source of authority, albeit that it could be represented as objective scholarship, in the curious gematria-like method of scriptural interpretation used by John Hutchinson: for on the acceptance of that alone rested their willingness to adhere to sola scriptura.

In speaking of the common Counter Enlightenment characteristics of Non juring, and in particular Usager thought and Hutchinsonianism, one might draw attention also to Usager sacramentology and the Hutchinsonian "recognition of the sacramental character of the world, and of the part played by typology in Scripture. ${ }^{\prime 89}$ One might proceed further with reference to Law's adoption of Behmenist analogy, in which analogy was pressed to the point of identity, or, again, to Butler's doctrine of analogy, or the way in which such themes of both the Hutchinsonians and Butler recur in tractarian writings. The matters of which the Usagers spoke - both sacramentology and the use of history as a source of authority - were prominent in the minds of those, contemporaries or successors, who carried on a Counter Enlightenment struggle. If the precise solutions which the Usagers offered to the difficulties they faced have been seen, as they were at the time by such as Leslie, to be less than adequate, these were nevertheless fashioned, often with considerable insight and scholarly skill, from what many others have held to be the appropriate matter. In addition to their character as a benchmark in the debate which was the English Enlightenment and Counter Enlightenment, this circumstance should ensure continuing attention to the Usagers.

88. George Horne, The Works of the Right Reverend . . Late Lord Bishop of Norwich . . . 6 vols. (London, 1809), 1: 209.

89. G. Rowell, “' 'Church Principles' and 'Protestant Kempism': Some Theological Forerunners of the Tractarians," in From Oxford to the People: reconsidering Newman and the Oxford Movement, ed. p. Vaiss (Leominster, Heref.: Fowler Wright, 1996), 17-59, here 22. A. J. Kuhn, like Rowell, argues for the enduring importance of this aspect of Hutchinsonianism. See his "Glory of Gravity: Hutchinson vs. Newton," Journal of the History of Ideas, 22, no. 3 (JulySeptember 1961): 303-22. 